\title{
Nigerian water bodies in jeopardy: the need for sustainable management and security
}

\author{
Y. N. Lohdip \& J. J. Gongden \\ Department of Chemistry, University of Jos, Nigeria
}

\begin{abstract}
The problems of supplying sufficient and sustainable potable water when needed or where it is wanted in sufficient quantities and qualities are acute in Africa. African's problem is not that of scarcity alone but the uncontrollable pollution of the available water bodies in both urban and rural areas. Most dams have become 'dams of death' due to the complexity of disease-causing organisms and toxic substances they contain. The UN declared 2005-2015 the 'water for life decade' with a focus on water related issues, but half of the period is gone without much impact being felt on the continent in terms of accessibility, sanitation, proper management and security. Nigeria is faced with the challenges of oil spillage in the south which has killed virtually all aquatic life forms and rendered the people without potable water for domestic use. Also ravaging the country is the indiscriminate dumping of refuse in lagoons, ponds and rivers in the west, gully erosion which has turned most rivers in the east into 'death traps' and the deserted dams and rivers in the northern part of the country. This paper investigates the past and present situation of the Nigerian water bodies in terms of capacity, accessibility/usage, management and security. Natural and artificial factors responsible for these changes are being explored and possible solutions suggested for remedying the challenges for sustainable management of the available water resources.
\end{abstract}

Keywords: water stress, pollution, contamination, water borne diseases.

\section{Introduction}

Water is essential for the maintenance of all life forms, the environment and development. Its uses fall into several major classes, each of which is associated with certain quantity and quality requirements. These classes include water for 
drinking, waste disposal, crop production, aquaculture, livestock, industrial use, navigational use, recreational uses and ecological values such as survival of natural lake, riverine or wetland communities [1]. This precious resource constitutes about $70 \%$ of the earth [2]. Under normal circumstances, this quantity of water is enough for all the uses for which it is meant. However, the situation is the opposite in most developing countries of Africa and Asia.

Despite the abundant water resources and the quantum of funds budgeted for the water sector annually, a large population in Nigeria still does not have access to this essential need of man, due to natural and human factors. For example, out of the 85 million people living in urban and semi-urban areas, less than half have reasonable access to reliable water supply. Many households end up purchasing water from private vendors instead of from the public supply [3]. In March 2012, the Federal Ministry of Water Resources estimated that only 58 per cent of Nigerians have access to potable water, while 38 per cent have access to effective sanitation [4]. Presently, the current water supply coverage in rural areas is $40-50 \%$ for which groundwater is the most widely used option [5]. This is because most of the surface waters (rivers, streams, dams, lakes, etc) are in a state of jeopardy, due to lack of management and security, climatic changes and man's continued destruction of the environment through his activities.

Recently, balancing the biophysical capabilities of the water resources against the multitude of uses that may affect it seems to be given less priority in Nigeria. This is because different societies, cultures and regions have different priorities based on their water-related needs. For example, while some considers aquatic life forms as more important in terms of their water need, others look at irrigation for dry season farming, hydro-power generation, and domestic uses as topmost priority. In managing water quality needs of the people, attention must be given to the purpose for which the water will be used. In Nigeria, water quality is generally deteriorating especially around the urban areas with high population growth. Direct pollution of water bodies through industrial and other municipal waste discharges seem to be attracting less attention because the enforcement of effective water quality laws and regulations in order to secure and manage the water resources in the country, is not yielding results. Identifying the uses for which a water resource will be managed is necessary and an important step towards management for sustainable uses.

\section{Overview of water resources in Nigeria}

Nigeria is blessed with abundant water resources for various purposes. The country has quite a number of small and big rivers and dams, the full extent of which cannot be accurately stated as they vary with season and from year to year. The total rainfall of the country decreases from the coast northwards, with the south having an annual rainfall ranging between $1500-4000 \mathrm{~mm}$ and the extreme north between 500-1500mm [6]. Major rivers according to Ita and Sado [7] cover about $10,812,400$ hectares which make up $11.5 \%$ of the total surface area of the country, estimated to be approximately $94,185,000$ hectares. The 
country is well-drained with a reasonably close network of rivers and streams (Figure 1).

Generally, five drainage systems can be identified in Nigeria (Martins [1]):

i. The Niger-Benue river system

ii. The Lake Chad system

iii. The Cross River Basin

iv. The Anambra River Basin and

v. The Ogun-Oshun Basins

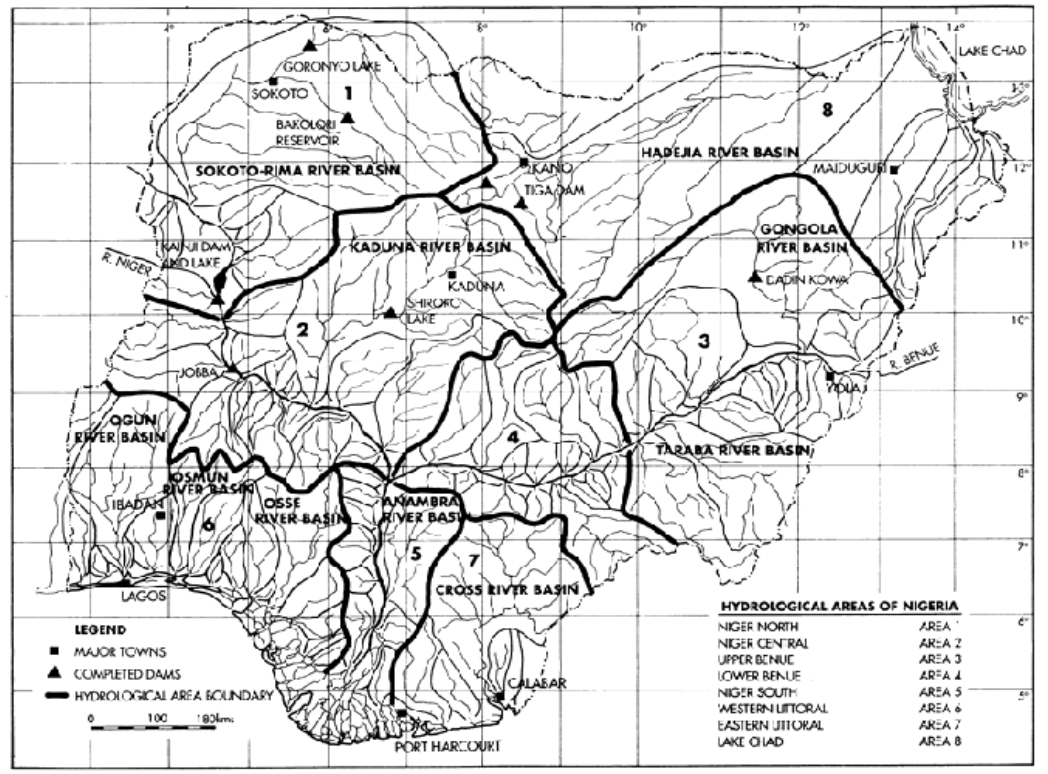

Figure 1: $\quad$ The hydrological areas of Nigeria.

From the annual total rainfall of $560 \mathrm{~km}^{3}$, surface run-off is estimated at 215 $\mathrm{km}^{3} / \mathrm{yr}$, which is distributed among the major drainage systems. The NigerBenue account for $127 \times 10^{9} \mathrm{~m}^{3}$, Chad $\left(0.63 \times 10^{9} \mathrm{~m}^{3}\right)$, Anambra/Cross Rivers (66 x $\left.109 \mathrm{~m}^{3}\right)$ and Ogun/Osun $\left(22 \times 10^{9} \mathrm{~m}^{3}\right)$. These drainages are made up of mostly rivers and streams with the smaller ones concentrated in the north which dry up during the dry season. The Lake Chad basin in the northeast with an area of $179,282 \mathrm{~km}^{2}$, or $20 \%$ of the total area of the country is the only internal drainage basin in Nigeria [8]. The largest coverage of the country's surface area comes from the Niger Basin with an area of $584,193 \mathrm{~km}^{2}$ (which is $63 \%$ of the total area of the country) and situated in the central and northwestern part of the country. Important rivers in this basin include the Niger and its tributaries (Benue, Sokoto and Kaduna rivers).

Dams and reservoirs in Nigeria are mostly used for domestic water supply, irrigation and hydro-electric power generation. One major difference between the northern and southern parts of the country is in the distribution of water 
resources. While 95\% of the country's dams are situated in the central and northern part of the country where rainfall is low, the south and west are characterized by big seas/lakes and rivers. The vast distribution of these water bodies within the country makes Nigeria rich quantitatively.

\section{Degradation and loss of water bodies in Nigeria}

Of the considerable water bodies distributed all over the country for various purposes, it is sad to note that the present state of this life-sustaining liquid is in a state of 'jeopardy' due to artificial and natural factors. These factors are in most cases 'preventable' if given the necessary attention by the three tiers of government and the communities within which the water bodies are situated. Even though natural factors may be responsible for the degradation of the environment, man's ignorance and unintentional actions have been attributed to be some of the major causes of environmental resource degradation including water. The factors responsible for the degradation of water bodies in Nigeria are in most cases peculiar to particular region of the country and differ from region to region.

\subsection{The menace of gully erosion in the East}

Gully erosion can be defined as the formation of vertically walled channels in soils caused by the dislodgement and carrying away of soil materials by concentrated but intermittent flow of water, usually during and / or immediately after heavy rains [9]. It usually starts unnoticed as a result of raindrop impact, washing away by running water which creates rills that later develop into gullies [10]. The status of the southeastern part of Nigeria as a rainforest zone has now been devastated by the action of gullies [11]. The environment which used to be habitable has now turned into a silent killer with hundreds of people, villages and farmlands being affected by the disaster. Southeastern rivers accessible to mankind hitherto, are now death zones because the impact of gully erosion has widened the rivers with most points of usage (by man) eaten up by gullies, turning the points into death traps. The river banks are weak due to the fragile and friable nature of the soil which easily collapses such that villagers find it difficult to access the water (Figure 2).

Most of the causes of erosions are traceable to bad management practices such as construction of roads without proper drainage or catchment pits, unguided cultivations that cause flooding which normally wash domestic and agricultural wastes into rivers and other water bodies use for domestic purposes. Rainfall plays an important role in the rapid development and growth of gullies which is demonstrated by the fact that major landslides and slumping occur after heavy rain [12]. According to the report, there were 5,700 erosion sites nationwide with 4,000 of this figure in the eastern part. This figure has since increased significantly. Numerous new gullies have emerged and many of the old ones have grown rapidly to disaster levels. The Nanka Erosion gullies in Anambra State are the most complex single erosion site in the world [13]. The 
situation is getting worse as many land resources are being swallowed day by day and water bodies being lost with the attendant outbreak of water borne and related diseases.

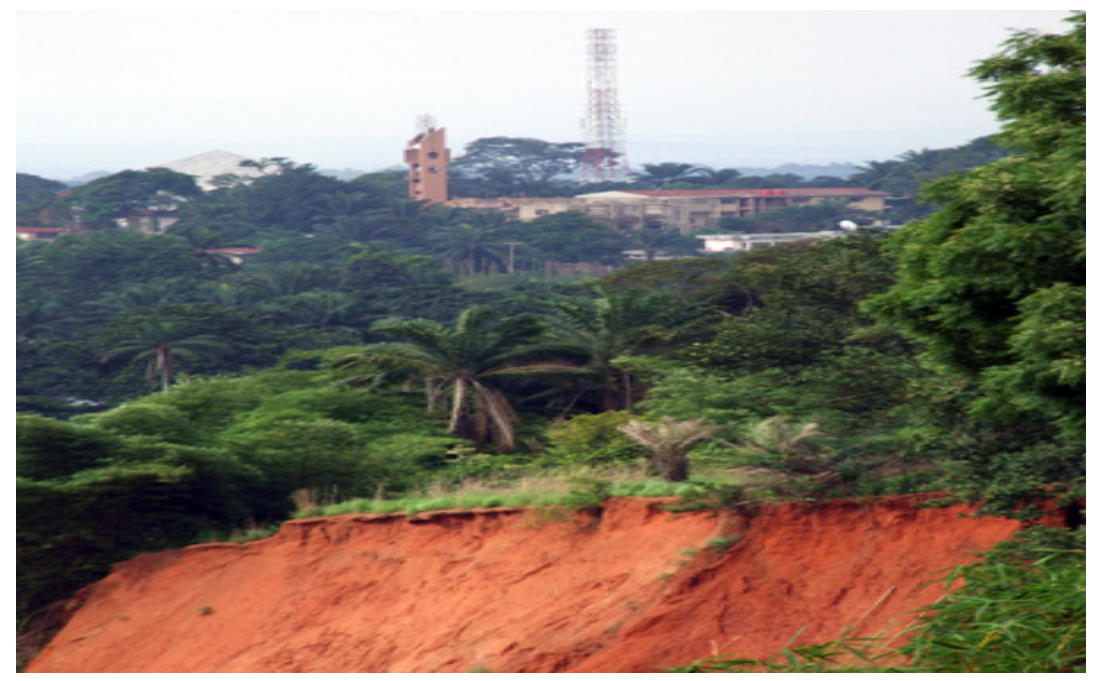

Figure 2: Collapse of river bank as a result of gully erosion in Southeastern Nigeria.

\subsection{Oil spill and water need in the South}

The inability of the Nigerian government to handle and solve the problem of oil spillage in the south-south geopolitical zone of the country is a contributing factor to the lingering crisis in the country. A situation where a community is completely left without water to drink because both the surface and ground waters have been impacted by oil seepage during the process of extracting crude oil, is unacceptable. Human and aquatic lives are being endangered without adequate compensation or measures to provide potable water to the communities [14].

Pipeline vandalization, kidnapping of foreign nationals and militant takeover of oil facilities in the Niger Delta, are problems that are resurfacing after the agreement reached by the Federal government and the communities involved. This is a clear evidence that oil spill is not an isolated problem, but one that has far-reaching multiplier effects [15]. After affirming that oil pollution in Ogoni land had contaminated both surface and ground water sources at levels more than 900 times above the World Health Organization-prescribed safety limits, the United Nations Environmental Program, UNEP called on the Nigerian authorities to compel the multinational oil companies operating in the areas to clean up the pollution caused by decades of oil exploration activities in the area [15]. Oil spill is a disaster ravaging the people's health and recklessly wasting them economically. Fishes no longer survive in the oil-polluted waters and some communities don't have potable water (Figure 3). 


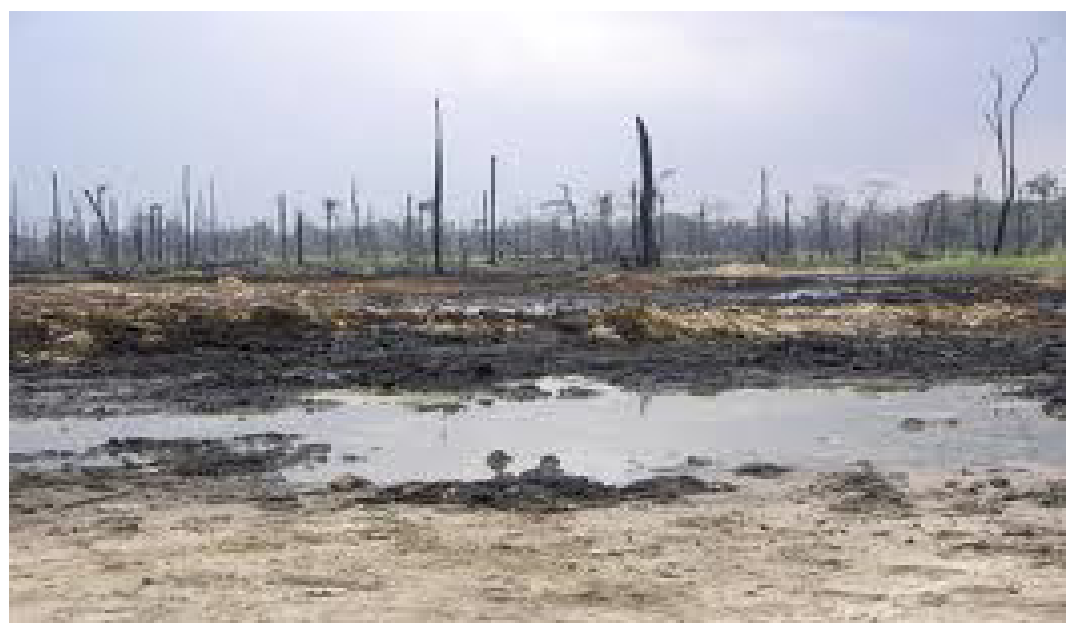

Figure 3: $\quad$ Oil spillage in the Niger Delta.

\subsection{Desert encroachment in the North}

Desertification is a type of land degradation in which a relatively dry land region becomes increasingly arid, typically losing its bodies of water as well as vegetation and wildlife [16]. Northern states like Katsina, Jigawa, Kano, Borno, Sokoto, Adamawa, Taraba, Kaduna, Kebbi and some parts of Plateau that have ecological and desert encroachment problems, face problems like water scarcity, crop failure, loss of livestock, famine, malnutrition and distress migration [17]. Figure 4 shows the devastating effect of drought on crops. Natural factors like high temperatures and reduced rainfall are responsible factors for this disaster. Temperature changes affect the amount of runoff that becomes groundwater-the main source of water supply in many parts of the country. The reduced rainfall evidenced by the low water tables increases the water stress and problem of environmental sustainability and water resource management in this region of the country.

The increasing need for wood fuel for domestic use has caused the rapid depleting of trees which has caused increasing havoc on the environment and put farming activities at great risk. In Kano for instance, massive irrigation activities are going on year in year out through the Hadejia Jam'are River Basin Development Authority [18]. Even though there are about six major dams like the Tiga, Challawa and sixteen smaller ones in the state, yet it cannot feed itself or eliminate the cases of desert threats. Where there seems to be increase in rainfall in the north in a particular year, dams get filled up to capacity, leading to collapse and eventual flooding of the whole area. Of course the result is always outbreak of water borne diseases like cholera, hepatitis, dysentery and diarrhea [19].

One of the worst affected areas by desert encroachment is Yobe State where sand dunes are encroaching at a rate of 30 hectares a year, taking over many 
villages. The depth of hand dug wells and boreholes are thrice as deep as those obtainable in the western part of the country. In some villages, getting access to water in the dry season takes hours of trekking to buy from water vendors whom themselves fetch directly from surface dams. Most rivers and other water bodies become dry in the dry season with desert swallowing up many.

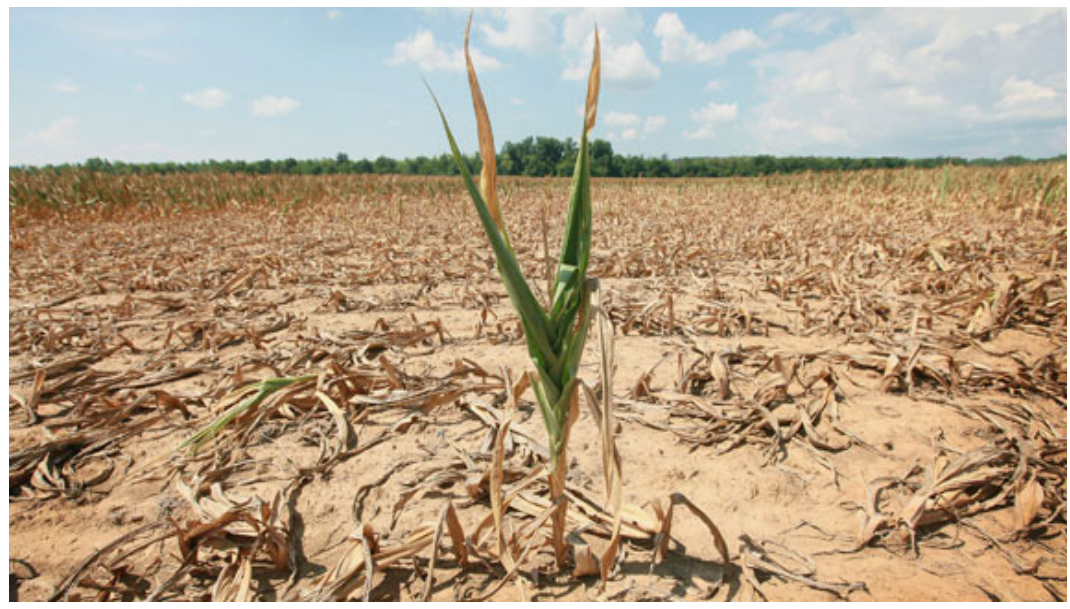

Figure 4: Crops drying up due to lack of rainfall in the Northern part of Nigeria.

\subsection{Waste disposal and water quality in the West}

With increasing urban population due to better employment opportunities as a result of concentration of industries in the southwestern part of the country, municipal solid waste management gets the lowest priority, mainly because disruptions and deficiencies in it do not directly and immediately affect public life and cause public reaction [20]. Lack of space and proper municipal bodies to manage the waste generated from residential, commercial and institutional bodies, has forced most people to dump their solid waste in any available space within the town, most of which are river banks and lagoons which are used by man for fishing and some domestic purposes (Figure 5). Heavy rain normally washes the waste into water bodies which contaminate rivers that are used by communities with non-public water supply.

In an effort to address the issue of waste dumping in the water ways, the Lagos State government has set up different environmental monitoring units to tame the menace associated with refuse dumping and other environmental degradation activities within the state. For instance, the Sanitation Services Department is responsible for ensuring a clean environment for healthy and sustainable living in line with the policy of an integrated approach to environmental sanitation and enhancement. The department organizes seminars on environmental advocacy/awareness campaign for the informal sector (artisans, market men and women, taxi drivers, etc). The department also 
organizes monthly environmental sanitation for civil servants (in private and public sectors) to clean up their houses and the surroundings under strict supervision by the departmental labour force [21]. Seminars on waste management and disposal are also organized and key resource personnel invited to educate the public on these issues [21].

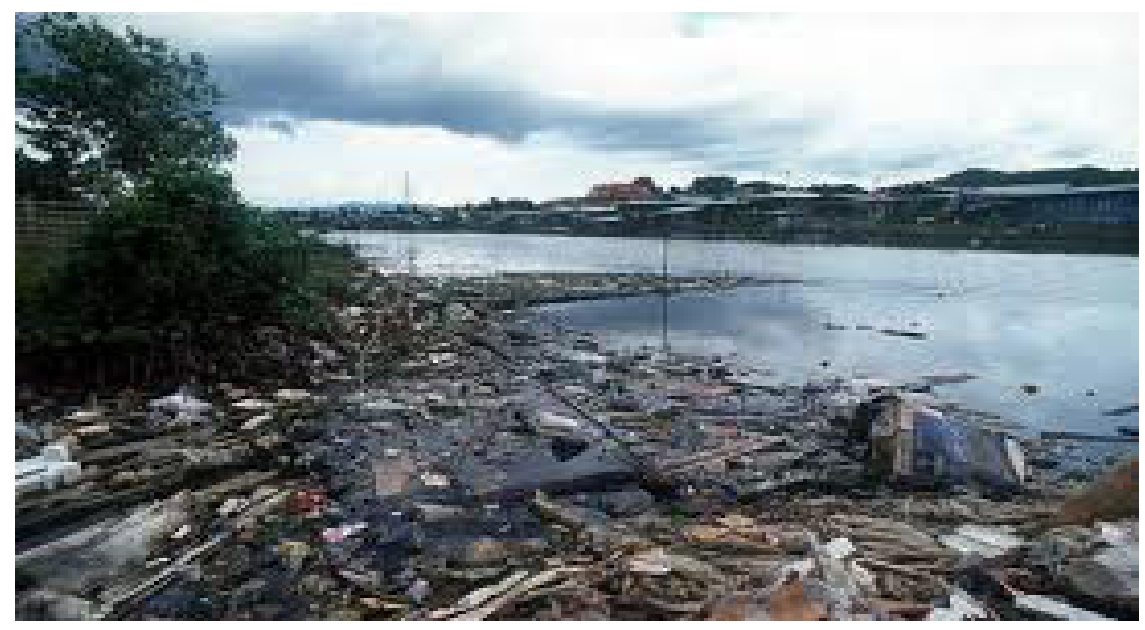

Figure 5: $\quad$ Waste dumping in rivers in the West.

The over-concentration of industries and the uncontrolled discharge of effluents from food and beverages, breweries, metal works, petroleum refinery, soap and detergents, textiles, paints, chemicals, plastics and other process industries into the environment are raining heavy havocs on both human and aquatic health. The pollutants from these effluents have been identified as being responsible for major health and environmental problems such as motor neuron disease [22, 23], reproduction disorders [24] and cardiovascular diseases [25]. The southwestern problem is not that of water scarcity, but pollution of the available ones without concern about the detrimental effect the result may cause.

\section{Our approach}

In an effort to tame the menace of water borne diseases in some parts of the country, our research group has over the past five years been studying the water problems ravaging some communities within the central part of the country with far reaching results [26-28]. The rural communities of Kwaikong, Wubang, Mabudi and Mangwang in Langtang South Local Government Area of Plateau State, Central Nigeria fall into the category of such distressed communities. The only available sources of water are artificial surface dams, dugged through communal efforts. Unfortunately these dams dry up during the dry season between February and June. Schistosomiasis, intestinal helminthes and diarrheal 
cases are common during the rainy season while typhoid fever, cholera, dysentery and hepatitis are characteristics of the dry season.

Sustainable low-cost treatment approaches were carried out on the water after a careful study of the biosorptive and antimicrobial capacity/activity of some waste agricultural biomasses locally sourced within the communities [27]. Locally activated nanoclay and charcoal were found to be excellent filter media. $0.3 g$ powder of Nymphea ampla (water lily) was effective in adsorbing cadmium, lead and nickel (83.60-93.34\%), while 0.5g of a 2:1blends of Corchorus olitorius (Jute) and Colocasia esceulenta (cocoa yam) roots were good adsorbents for zinc, arsenic, copper, manganese and mercury (62.32-90.00\%). The high microbial loads recorded in the untreated water $\left(2.78 \times 10^{2}-3.08 \times 10^{2}\right.$ TVC/ 24hrs) was completely reduced to the barest minimum of less than $1.0 \mathrm{x}$ $10^{1} \mathrm{TVC} / 48 \mathrm{hrs}$ with $1.5 \mathrm{~g} / \mathrm{L}$ of Carica papaya (pawpaw) leaf powder.

In addition, a potable pilot scale water purification system has been constructed with all the materials locally sourced from within the communities [28]. This locally fabricated water purification system has been shown to be effective and is sustainable for small family sizes.

\section{Water security, management and sustainability}

Water resources management and security must be taken seriously in Nigeria to ensure the long-term sustainable use of it for future generations. It is good to note that the three tier of government (federal, state and local) are all saddled with the responsibility of supplying water of good quality to the citizens [26]. While the federal is in charge of water resources management, the state government has the responsibility of supplying water to urban cities while rural water supply is carried out by the local government and the communities.

Poor management and maintenance of water supply systems, inadequate funding, misuse of water project funds, insufficient relevant manpower, haphazard implementation, lack of a national policy for water supply, government's negligence and vandalisation of water supply systems and equipments are key to the dilapidating water supply situation in most parts of the country. According to the World Bank [29], water production facilities were rarely operated to capacity due to broken down equipment, lack of power or fuel for pumping, etc.

The urgent need for the ratification and full implementation of the National Water Policy (still in draft) like other environmentally related policies is imminent. This is because it will improve the nation's water resources management, including the management of hydrological risks and vulnerabilities [30]. The government and all stakeholders in the water business must be on the watch out for anybody, community, industry or institution trying to frustrate their efforts at ensuring safety of all water bodies within the Nigerian territory. Diverse agencies using water for different purposes need to have their activities properly planned, coordinated and managed with a view to conserving this scarce but all important resource for tomorrow. 
Tree planting effort and construction of large surface dams by most of the northern states governors must be encouraged and continued in order to reduce the hardship brought by desertification on the people. The law must take its stand on all agricultural activities involving bush burning, deforestation and tree felling for firewood and building purposes in the south west. This will augment government effort at arresting environmental degradation by gully erosion. Afforestation must be encouraged within fragile and friable soils while road construction / excavations discouraged within these areas. Internationally, where there is a spill, the polluter should pay for the cost and damage.

However in Nigeria, whether an oil spill has been as a result of accident, operational failure, deliberate sabotage, negligence to take adequate measures or refusal to act, there is as yet no legal mechanism or structure for determining mode of paying compensation or recovering damages [31]. In some cases, no compensation is made and the communities left to suffer the damages. If the multinational oil companies responsible for oil spillage are closed down by the government because of any act of spillage on the environment which pollutes the water, killing all aquatic life forms and rendering the waters unfit for drinking, it will go a long way in reducing this silent killer. Laws and policies must not only be set, but strict enforcement in order to safe guards the environment. Wastes must be properly treated and discharged in appropriate places, far from water bodies in order not to contaminate them. Defaulters should not only be made to pay damages but forced to provide water for the affected communities. It is time to enforce the law of the land on everybody as is been done in developed countries. This will help in protecting and maintaining environmental resources, especially water

\section{Conclusion}

Though clean drinking water has been a scarce resource in Nigeria, the scarcity has been compounded by the devastating effect of global climate change, sweeping across the nation. If the environment is protected, resources are saved. This protection is the responsibility of the government of every nation and must not be taken for granted. Access to clean water is a human right, and should be so enshrined in national law. Good water quality standards can be maintained by water supply undertakings to guarantee affordable access for the poor to this basic human need at appreciable level of supply. There should be proper and regular evaluation of the performance of all sectors saddled with the responsibility of maintaining and supply of water in every community. In the absence of this, research bodies, non-governmental organizations and all stakeholders in the water and environment business must rise up to their responsibilities towards curtailing this evil that engulfed the water bodies. 


\section{References}

[1] Martins (2001). Water resources management and development in Nigeria: Issues and challenges in a new millennium. Inaugural lecture delivered at the University of Agriculture, Abeokuta - Nigeria on 22 ${ }^{\text {nd }}$ August 2001.

[2] USGS (1984). The Hydrologic Cycle. Retrieved 01.02.2013.

[3] Abaje, I.B, Ati,O.F, and Ishaya, S. (2009). Nature of Portable Water Supply and Demand in Jema'a LGA of Kaduna State, Nigeria. Research Journal of Environmental and Earth Sciences 1 (1), 16-21.

[4] Iroegbu-Chikezie, O. and Ochigbo, F (2012). http://www.thenation onlineng.net/2011/index.php/business/404html Retrieved 4/2/2013.

[5] Onugba, A and Yaya, O.O (2010). Sustainable Groundwater Development in Nigeria. Issues and Challenges in a New Millenium. University of Agriculture, Abeokuta. 22.08.2001.

[6] Food and Agriculture Organization of the United Nations (2012). Aquastat's FAO Information System on Water. www.fao.org/nr/water/aquastat/nigeria. Retrieved 02.02.2013.

[7] Ita, E.O, Sado, E.K, Balogun, J.K, Pandogari, A and Ibitoye, B (1988). “A preliminary checklist of Inland Water Bodies in Nigeria with special reference to Lakes and Reservoirs”. Kainji Lakes Research Institute. Retrieved 22.05.2012.

[8] Asokoro-Ogaji, C (2011). Importance of water resources to food production. http://comfortasokoroogaji.wordpress.com/2011/09/19/ importance-of-water-resources-to-food-production-by-comfort-asokoroogaji-asokoro_idihymail-com/ Retrieved 17.01.2013.

[9] Akpokodje, E.G, Akaha, C.T and Nnamdi, E (2010). Gully Erosion Geohazards in Southeastern Nigeria and management implications. Scientia Africana. 9 (1).

[10] Nwilo, P.C, Olayinka, D.N, Uwadiegwu, I and Adzandeh, A.E (2011). An assessment and mapping of Gully Erosion Hazards in Abia State. A GIS Approach. Journal of Sustainable Development. 4 (5).

[11] IRIN Africa (2011). Nigeria: Erosion a 'State of Emergency'. www.irinnews.org. Retrieved 02.02.2013.

[12] World Bank (1990). Towards the development of an Environmental Action Plan for Nigeria. World Bank, Washington D.C. 139.

[13] Okanigbo, F. O. R (1998). Erosion Menace in Anambra State: Government efforts at combating it. Proc. Int. symposium on Erosion in Southeastern Nigeria. Pp 120-125.

[14] Amaku, K (2012). Taming the ravage of oil spill. The Nation Newspaper. 18.10.20.

[15] Odogwu, G (2012). Oil spill in Nigeria: Bite, NOSDRA, Bite!. The Punch Newspaper. Dec. 27, 2012. Retrieved 30.12.2012.

[16] Geist, H. (2005). Desertification http://en.wikipedia.org/wiki/ Desertification \#cite_ref-Geist-2005-p2_2-0 Retrieved 4/2/2013.

[17] Askira, A and Sabo, H (2012). Desert Encroachment Killing North. Youths against Disasters. www.yadnigeria.wordpress.com. 
[18] Ovie, S.I and Raji, A. (2006). Food Security and Poverty Alleviation through improved valuation and governance of River Fisheries in Africa. Fisheries Co-management in Nigeria: An analysis of the underlying policy process. National Institute for Freshwater Fisheries Research, New Bussa, Niger State, Nigeria.

[19] UNDESA (2012). Water Quality. International Decade for Action. 'Water for life' 2005-2015. www.un.org/waterforlifedecade/quality.

[20] Saidu, M (2011). Effect of Refuse Dumps on Groundwater Quality. Pelegia research library. www.pelegiaresearchlibrary.com.

[21] Lagos State Government (2012). www.lagosstate.gov.ng/ministry of environment.

[22] Iwani, O, Mom, C.S, Watanabe, T and Ikeda, M (1994). Association of metal concentrations in drinking water with incidence of motor neuron disease in a focus on the Peninsula of Japan. Bulletin of Environmental Contamination and Toxicology. 52 109-116.

[23] Adenuga, A.O, Ogunjiuba, K and Obuche, F. K (2006). Sustainability of the Environment and Water Pollution in Nigeria: Problems, Management and Policy Options. Global Journal of environmental sciences. 5 49-59.

[24] Mantovani, A (1993). Reproductive Risks from Contaminants in Drinking Water. Super Sanita 29 317-326.

[25] Clayton, D. G (1976). Water Hardness and Cardiovascular mortality in England and Wales. Proceedings of the European Scientific Colloquium. Pp $323-340$.

[26] [26] Lohdip, Y. N (2011). 'The Insolvency of the Universal Solvent: That All May Have Enough to Drink'. $52^{\text {nd }}$ Inaugural Lecture of the University of Jos, delivered on Friday 29 $9^{\text {th }}$ July, 2011.

[27] Lohdip, Y. N and Gongden, J. J (2012). 'Sustainable Low Cost Water Treatment for Some Nigerian Rural Communities'. Proceedings of the Conference on "Water Management Issues in Africa”. Network of African Science Academies (NASAC) - Royal Netherlands Academy of Arts and Sciences (KNAW), 156-160. Reduit, Mauritius, 28-31 March 2012.

[28] Gongden, J. J and Lohdip, Y. N (2012) Green Approaches to Water Treatment Using Indigenous Materials. Paper presented at the Pan Africa Chemistry Network (PACN) - Nigeria Conference on Health, Water and Waste - Learning and Working Together, held at the Eko Hotel, Lagos Nigeria $2^{\text {nd }}-4^{\text {th }}$ July 2012.

[29] World Bank (2010), New Project to bring clean water to 50000 household. http://www.worldbank.org/en/country/nigeria Retrieved 4/2/2013.

[30] Oladipo, E (2010). Towards enhancing the adaptive capacity of Nigeria. A review of the country's state of preparedness for climate change adaptation. A report.

[31] NOSDRA (2012). Nigeria has highest oil spill in the World. News. 